\title{
Study The Effect of Cytomegalovirus and Luteinizing Hormone on Pregnancy and Spontaneously Abortion Assay by ELISA Technique
} https://doi.org/10.32792/utq/utj/vol10/1/1

\author{
Ahmed Naser Fayad \\ Thi-Qar university-College of Science-Department of Pathology Analysis
}

\begin{abstract}
In this study indirect ELISA test was conducted on 118 serum samples for Cytomegalovirus collected from women in different ages and cases in Bent AL-Huda hospital. Indirect ELISA was applied on all these samples depending on the optical density (OD) value of sera previously prepared from blood of well know healthy and non-vaccinated women. According to ages groups the higher ratio are $(56.5 \%)$ was observed in first age group. A highly significant differences were observed in the seropositivity concerning to age groups $(\mathrm{P}<0.01)$. According to Cases groups the higher ratio of seropositivity were found in women $(75.61 \%)$ was observed in Recurrent abortion and then in Bleeding $(75 \%)$. The Quantitative ELISA test was used to detect the Luteinizing hormone as antigens in same serum samples. the higher rate of Luteinizing hormone positivity was observed in the last age groups $(83.33 \%)$. there was a highly significant difference between the ages groups. Depending on Cases the higher rate of Luteinizing hormone positivity was (87.50\%) in bleeding case , there was highly significant difference in the Luteinizing hormone in Cases groups of Quantitative ELISA.
\end{abstract}

\section{Introduction}

with young children or through sexual transmission Cytomegalovirus infection tends to cause few symptoms in Human Cytomegalovirus (CMV) is a member of Herpesviridae family, and therefore has the ability to establish latency following primary infection(1). Primary infection occurs in seronegative, susceptible host. Recurrent infection represents reactivation of latent infection or reinfection of seropositive immune host. Disease may result from primary or recurrent infections, Cytomegalovirus the former is more commonly associated with sever disease(2). Primary infection often produces no symptoms or mild non-specific symptoms(3). Cytomegalovirus is spread through contact with infected body fluids, such as urine or saliva. Infection among pregnant women most frequently occur through close contact immuncompetent individuals, but can serious disease among HIV-infected persons, organ transplant recipients on immunosuprresive therapy, and fetuses(4). Cytomegalovirus is the most common congenital infection and the leading cause of sensorineural hearing loss, mental retardation, retinal disease, and cerebral palsy(5).Cytomegalovirus is the largest of the herpesviruses, and has a diameter of $200 \mathrm{~nm}$ with douple-stranded DNA viral genome of $240 \mathrm{~kb}$ in a $64 \mathrm{~nm}$ core enclosed by an icoshedral capsid composed of 162 capsomers. The core is assembled in 


\section{University of Thi-Qar Journal Vol.10 No.1 Mar 2015}

Web Site: https://jutq.utq.edu.iq/index.php/main Email: journal@jutq.utq.edu.iq

nucleus of the host cells. The capsid is surrounded by a poorly defined amorphous tegmument, which itself surrounded by a loosely applied lipid-containing envelope. Mature viruses exit the cells by reverse pinocytosis (2). The prevalence of infection is quite variable as it varies in different geographic regions, different ethinic populations, and different socioeconomic level communities(6). The prevalence increase with age, and is higher in developing countries and among lower socioeconomic strata of the more developed nations(2). Transmission sources of Cytomegalovirus include saliva, breast milk, cervical and vaginal secretions, urine, semen, stools, blood and tissue or transplants. The spread of Cytomegalovirus requires very close or intimate contact because it is very labile. Transmission occurs by direct person-to-person contact, but indirect transmission is possible via contaminated fomites (2). Transmission can be horizontal via direct human-human contact and with sexual activity. Vertical transmission can occur during pregnancy, delivery, and breast feeding. The virus shedding from cervix increases as the pregnancy advances in gestation(7).

The incidence of infection in pregnancy is estimated to be as high as 1 to 200 pregnancies, of which around $40 \%$ will result in fetal infections(3). Congenital Cytomegalovirus occurs in $0.05 \%-1.5 \%$ of births ${ }^{(4)}$. Higher rate of infection among populations with lower economic standard of living. The risk of fetal infection is greatest with maternal primary Cytomegalovirus infection 30\% and much less likely with recurrent infection $<1 \%$ (5).

Rate of transmission of Cytomegalovirus infection are 3-7 times greater in infant born to adolescent mothers(5). Perinatal transmission is common, accounting for an incidence of $10-60 \%$ through the $1^{\text {st }} 6$ moths of life. The most important perinatal sources of virus are genital tract secretions at delivery and breast milk. Among Cytomegalovirus seropositive mothers, virus is detectable in breast milk in $96 \%$, with postnatal transmission occurring in approximately $38 \%$ of infant (8). About $90 \%$ of infected infants are asymptomatic(3).

\section{Materials and MethodsDiagnostic Kits}

The BioCheck Cytomegalovirus (CMV) IgM ELISA kit: designed to detect CMV specific antibodies in human serum samples / BioCheck / Inc.The Veda. Lab. Luteinizing hormone (LH) glycoprotein ELISA kit: designed to detect LH hormone glycoprotein in human serum samples/ Veda. Lab / France.Blood Samples The blood samples were collected from the women in Bint-Al huda hospital into $10 \mathrm{ml}$ in sterile tubes without anticoagulant and were stored overnight at room temperature (18-25) $\mathrm{C}^{\circ}$ for serum separation . Ten blood samples were collected from each well known healthy non-vaccinated women and considered as control. The samples were then centrifuged at high speed 3000rpm for 5 minutes. The serum was transferred into a single clean, sterile cryovial to conserve at $-20 \mathrm{C}^{\circ}$ until assayed (9) 


\section{The BioCheck, Cytomegalovirus (CMV) IgM kit procedure}

The BioCheck Cytomegalovirus (CMV) IgM ELISA kit procedure was done according to the instructions of BioCheck Company kit, starting with dilution till a blue-green color develops, which was due to the conversion of the substrate by the conjugate and read microtitre plate by microphometer at measured optical density (OD) $450 \mathrm{~nm}$. The corrected OD values(ODcorr) as to the following equationOD $\mathrm{CMV}$ $\mathrm{IgM} \_\mathrm{OD}$ control $=\mathrm{OD}$ corr While the percent positivity Value $(\mathrm{PP})$ as in $\mathrm{PP}=\frac{\text { Test Sample or } \text { Neg(ODCorr })}{\text { Positive Control(ODcorr })} \times 100 \quad$ Interpretation of the results: Interpretation of test sample result as below:

$\begin{array}{lll}\text { Serum } & \text { PP } & \text { Interpretation } \\ & <50 & \text { Negative } \\ & \geq 50 & \text { Positive }\end{array}$

\section{The Veda. Lab. Luteinizing hormone ( $\mathrm{LH})$ glycoprotein kit procedure}

The Veda. Lab. Luteinizing hormone (LH) glycoprotein kit procedure was done according to the instructions of Veda. Lab. Company kit, starting with dilution till a blue-green color develops, which was due to the conversion of the substrate by the conjugate and read microtitre plate by microphometer at measured optical density (OD) $450 \mathrm{~nm}$.

The corrected OD values( $\mathrm{Y})$ as to the following equation

$\mathrm{Y}=-1.4+1.08_{(\mathrm{x})}$

$\mathrm{X}=\mathrm{OD}$ of Control

The values ranged from 0.1 to $150 \mathrm{mIU} / \mathrm{mL}$. the minimum detectable concentration of $\mathrm{LH}$ by this assay is $0.3 \mathrm{mIU} / \mathrm{mL}$.

Interpretation of the results: Interpretation of test sample result as below:

$\begin{array}{ccc}\text { Serum } & \text { PP } & \text { Interpretation } \\ & 1.68-15 & \text { Normal } \\ >15 & \text { High }\end{array}$

\section{Statistical analysis}

The statistical analysis of the data was calculated for ELISA test by using (SPSS Version 15).

Results and Discussion

Analysis of serum samples by Indirect \& Quantitative ELISA

From the 118 total serum samples examined by indirect ELISA for the presence of antibodies to the proteins of Cytomegalovirus, positive sera was observed in 10-20 years group with $13(56.5 \%)$ and in Quantitative ELISA were highest positive age group was observed in 41-45 years group with 5(83.33\%). 


\section{University of Thi-Qar Journal Vol.10 No.1 Mar 2015}

Web Site: https://jutq.utq.edu.iq/index.php/main Email: journal@jutq.utq.edu.iq

CMV seropositively according to age group of women

The seropositively results in all age group is highly significant levels indicate by ELISA technique as well as this results (10). Discussed presence of antibodies in the blood refers to increase of percentage in age group (10-20) and (21-30) with a percentages of $(56.50 \%)$ and (47.50), respectively(11).

In comparative study there is increase where due to a highly tolerance levels in group ELISA positive compare with age group of ELISA negative(12) ( table 1) .

Table(1): The seropositively against CMV according to Age group of women

\begin{tabular}{|c|c|c|c|c|c|}
\hline \multicolumn{2}{|l|}{ Women } & \multicolumn{2}{|c|}{ ELISA Positive(+) } & \multicolumn{2}{|c|}{ "ELISA Negative(-) } \\
\hline Age(years) & number & Number & percentage & number & Percentage \\
\hline 年10-20 & 23 & 13 & (56.5\%) & 10 & (43.5\%) \\
\hline $21-30$ & 61 & 29 & $(47.5 \%)$ & 32 & $(52.5 \%)$ \\
\hline $31-40$ & 28 & 12 & $(42.9 \%)$ & 16 & $(57.1 \%)$ \\
\hline $41-45$ & 6 & 2 & $(33.3 \%)$ & 4 & $(66.7 \%)$ \\
\hline The total & 1118 & "56 & (47.5\%) & 62 & (52.5\%) \\
\hline
\end{tabular}

$\mathrm{P}=$ Proportion values in Chi-square .

hormone seropositivity according to Age group of women

The result show in table (2) that in the increase levels of LH hormone (13) ( induction of ovulation hormone) in age group (41-45) with percentage of ( $83.33 \%)$ and age group (31-40) with percentage of (71.43\%) respectively (14).

This variation in percentage of highly significant increase of hormone in larger age group compared with smaller age group (15).

The positive strong effect of this advance age significantly reflected the percentage of increase hormone which is influence directly on the hormonal balance in blood serum and refer to the presence of CMV in results of ELISA positive compare to $\mathrm{E}$ LISA negative in this study (16).

This correlation refer to positive results in significantly in positive compare to no significantly (17).

Table(2): The seropositively against LH hormone according to Age group of women

\begin{tabular}{||l|l||l|l||l|l||}
\hline \hline Women & \multicolumn{2}{|l||}{ ELISA Positive $(+)$} & ELISA Negative(-) \\
\hline \hline Age(years) & number & Number & percentage & number & Percentage \\
\hline \hline $10-20$ & 23 & 16 & $(69.57 \%)$ & 7 & $(30.43 \%)$ \\
\hline $21-30$ & 61 & 25 & $(47.5 \%)$ & 36 & $(52.5 \%)$ \\
\hline $31-40$ & 28 & 20 & $(71.43 \%)$ & 8 & $(28.57 \%)$ \\
\hline \hline
\end{tabular}




\section{University of Thi-Qar Journal Vol.10 No.1 Mar 2015}

Web Site: https://jutq.utq.edu.iq/index.php/main Email: journal@jutq.utq.edu.iq

\begin{tabular}{||l|l||l|l||l|l||}
\hline \hline $41-45$ & 6 & 5 & $(83.33 \%)$ & 1 & $(16.67 \%)$ \\
\hline \hline The total & 118 & 66 & $(55.93 \%)$ & 52 & $(44.07 \%)$ \\
\hline \hline P $<0.01$
\end{tabular}

$\mathrm{P}=$ Proportion values in Chi-square .

Table(3): ELISA CMV and LH SE Values in relation to Age group.

\begin{tabular}{||l|l||l||l||}
\hline Women & CMV & LH \\
\hline \hline Age(years) & number & & \\
\hline $10-20$ & 23 & 11.3 & 19.57 \\
\hline $21-30$ & 61 & 2.6 & 2.1 \\
\hline $31-40$ & 28 & 7.1 & 21.34 \\
\hline $41-45$ & 6 & 16.7 & 33.34 \\
\hline \hline The total & 118 & 4.83 & 8.37 \\
\hline \hline \multicolumn{2}{|l|}{$\mathrm{P}<0.01$} \\
\hline
\end{tabular}

$\mathrm{P}=$ Proportion values in Chi-square .

$\mathrm{SE}$ value $=$ Stander error

Also in table (3) showed different SE value obtained by ELISA against CMV and LH in age group women.

CMV seropositivity according to Case group of women

In table (4) the seropositively of ELISA refers to presence of recurrent abortion percentage ( $75.61 \%$ ) may be due to either corpus luteum immaturation or chromosomal sex determination abnormalities (18) or due to Toxoplasmosis which is occurs in first Trimester ( the first the month of pregnancy) (19) . Congenital anomalies may be due to administration of drug for folic acid antagonists with percentage ( $61.90 \%)$ with ELISA positive compare with ( $24.39 \%)$ which is significantly results and highly strong positive correlation (20).

Pseudopregnancy may occurs in abnormal positive of pregnancy which may happened in ampoullary regions of fallopian tube, the Pseudo -pregnancy refers to HCG hormone in blood serum ( 10 days of pregnancy ) and ( 8 days) in urine (21).

Ectopic pregnancy occurs in external, peritoneum of abdominal cavity (22) . This case lead to fetal mistake and death (23).

Ectopic pregnancy present with abnormal uterine bleeding and unilateral pelvic pain, which must be differentially diagnosis from appendicitis, an a benting intrauterine pregnancy or a bleeding corpus luteum of a normal intrauterine pregnancy (24) . 


\section{University of Thi-Qar Journal Vol.10 No.1 Mar 2015}

Web Site: https://jutq.utq.edu.iq/index.php/main Email: journal@jutq.utq.edu.iq

Fatel death occurs in pregnancy women due to disturbance and disorder mistake in maternal-fetal circulation and prevention of reaching of adequate amount of blood to the fetus form placenta and umberical card ( 16) . in this study the high levels percentage due to occurs of this case in almost pregnancy women (26) .

Table(4): The seropositively against CMV according to Case group

\begin{tabular}{||c|c||c|c||c|c||}
\hline \hline \multicolumn{2}{|c|}{ Women } & \multicolumn{2}{c||}{ ELISA Positive(+) } & \multicolumn{2}{c||}{ ELISA Negative(-) } \\
\hline \hline Case & Number & number & percentage & number & percentage \\
\hline \hline Recurrent abortion & 41 & 31 & $(75.61 \%)$ & 10 & $(24.39 \%)$ \\
\hline Congenital anomalies & 21 & 13 & $(61.90 \%)$ & 8 & $(38.10 \%)$ \\
\hline Non pregnancy & 25 & 14 & $(56 \%)$ & 11 & $(44 \%)$ \\
\hline Ectopic pregnancy & 16 & 5 & $(31.25 \%)$ & 11 & $(68.75 \%)$ \\
\hline \hline Bleeding (unilateral pelivic) & 8 & 6 & $(75 \%)$ & 2 & $(25 \%)$ \\
\hline \hline Fetal death & 7 & 5 & $(71.43 \%)$ & 2 & $(28.57 \%)$ \\
\hline \hline The Total & 118 & 74 & $(62.71 \%)$ & 44 & $(37.29 \%)$ \\
\hline \hline
\end{tabular}

$\mathrm{P}=$ Proportion values in Chi-square .

LH hormone seropositively according to Case group of women

There is a highly significant correlation in seropositivity against LH hormone increase in recurrent and spontaneously abortion due to no secretion of HCG hormone as a test of pregnancy a s results of low value levels in this case as compare with normal pregnancy in uterine tube and region of fallopian canal (27) .

Unilateral pelvic pain due to prevention of continuous gestation as a result as a result of abnormal uterine bleeding of corpus luteum of abnormal intrauterine pregnancy (28) .

In this study the low levels of LH hormone in this assay ( fetal death, pseudo pregnancy, no pregnancy and congenital anomalies due to no presence and secretion as stimulation of anterior lobe of pituitary gland due to stimulation of GNRH and secretion of $\mathrm{LH}$ and FSH lead to highly associated with hormone inhibition and activity ( the feed back control) (29)(30) .

Also in table (6) showed different SE value obtained by ELISA against CMV and $\mathrm{LH}$ in age group women.

Table(5): Seropositively against LH hormone according to case group of women

\begin{tabular}{||c|c||c|c||c|c||}
\hline \hline \multicolumn{2}{|c||}{ Women } & \multicolumn{2}{c||}{ ELISA Positive(+) } & \multicolumn{2}{c||}{ ELISA Negative(-) } \\
\hline \hline Case & number & number & percentage & number & Percentage \\
\hline \hline Recurrent abortion & 41 & 34 & $(82.93 \%)$ & 7 & $(17.07 \%)$ \\
\hline Congenital anomalies & 21 & 15 & $(71.43 \%)$ & 6 & $(28.57 \%)$ \\
\hline \hline
\end{tabular}




\section{University of Thi-Qar Journal Vol.10 No.1 Mar 2015}

Web Site: https://jutq.utq.edu.iq/index.php/main Email: journal@jutq.utq.edu.iq

\begin{tabular}{||c|c||c|c||c|c||}
\hline \hline Non pregnancy & 25 & 12 & $(56 \%)$ & 13 & $(44 \%)$ \\
\hline Ectopic pregnancy & 16 & 6 & $(37.50 \%)$ & 10 & $(62.50 \%)$ \\
\hline \hline $\begin{array}{c}\text { Bleeding (unilateral } \\
\text { pelvic) }\end{array}$ & 8 & 7 & $(87.50 \%)$ & 1 & $(12.50 \%)$ \\
\hline \hline Fetal death & 7 & 4 & $(57.14 \%)$ & 3 & $(42.86 \%)$ \\
\hline \hline The Total & 118 & 78 & $(66.10 \%)$ & 33.90 & $(37.29 \%)$ \\
\hline \hline \multicolumn{3}{|c|}{$\mathrm{P}<0.01$} \\
\hline
\end{tabular}

Table(6): ELISA CMV and LH SE Values in relation to Case group of women.

\begin{tabular}{||c|c||c||c||}
\hline \hline \multicolumn{2}{|c|}{ Women } & CMV & LH \\
\hline \hline Case & NO & & 32.93 \\
\hline \hline Recurrent abortion & 41 & 25.61 & 21.43 \\
\hline Congenital anomalies & 21 & 11.9 & 6.1 \\
\hline Non pregnancy & 25 & 6.1 & 12.5 \\
\hline Ectopic pregnancy & 16 & 18.75 & 37.5 \\
\hline \hline Bleeding (unilateral pelvic) & 8 & 25.1 & 7.14 \\
\hline \hline Fetal death & 7 & 21.43 & 6.96 \\
\hline \hline The total & 118 & 5.86 & \\
\hline \hline
\end{tabular}

\section{References}

1. Mocarski, E.S.; Courcelle, C.T.; Lippincot Williams \& Wilkins. (2001). Cytomegaloviruses and their replication. Field Virology, $4^{\text {th }}$ ed.Boston : 26292673.

2. Stango, S.; Behrman, R. E.; Kliegman, R. M. \& Jenson, H.B. (2008). Nelson Textbook of Pediatric. 18th ed. Philadelphia, Pa: WB Saunders Co: 1377-1379.

3. Philip, N. B.(2006).Perinatal infection Cytomegalovirus Obstetrics by Ten Teachers. $18^{\text {th }}$ ed. BookPower : 203-204.

4. Guilherme ,L. \& Kalil, J.( 2004). Rheumatic fever: from sore throat to heart lesions. Int. arch. Allergy. Immunol.134: 56-64.

5. Clarnce, W. \& Gowen, J. (2011). Congenital Infection, Cytomegalovirus. Nelson Essentials of Pediatrics, $6^{\text {th }}$ ed. Philadelphia, Saunders: 260-261.

6. Barzilai,O.\&Sherer,Y.(2007).Epstein-Barr virus and Cytomegalovirs in Autoimmune Diseases. Ann. N. Y. Acad. Sci.; 1108: 567-577.

7. Kumar, S.( 2004). Fetal Infections. Obstetrics and Gynecology an evidencebased text for MRCOG, $1^{\text {st }}$ ed. Arnold, London: 235-236.

8. Joana, C. \& Gillhan,C.( 2004). Infections. . Obstetrics and Gynecology an evidence-based text for MRCOG, 1st ed. Arnold, London; 2004: 158-159.

9. Chibssa, T.R.(2006) .Participatory appraisal and seroprevalence study of foot and mouth disease in South Ethiopia; University of Addis Ababa, Pp1-85. 


\section{University of Thi-Qar Journal Vol.10 No.1 Mar 2015}

Web Site: https://jutq.utq.edu.iq/index.php/main Email: journal@jutq.utq.edu.iq

10. Toth, B. Fischl, A.; Scholz, C.; Kuhn, C.; Friese, K.\& Karamouti, M. (2009). Insulin and leptin receptors as possible new candidates for endocrine control in normal and disturbed human pregnancy. Mol. Hum. Reprod . 15(4):231-239.

11. Tian, L.; Shen H.; Lu, Q.; Norman, R.J. \& Wang, J.( 2007). Insulin resistance increases the risk of spontaneous abortion after assisted reproduction technology treatment. J. Clin. Endocrinol Metab. 92(4):14301433.

12. Glueck, C.J.; Wang, P.; Goldenberg, N.\& Sieve-Smith, L.(2002). Pregnancy outcomes among women with polycystic ovary syndrome treated with metformin. Hum Reprod. 17(11):2858-2864.

13. Eisenhardt, S.; Schwarzmann, N.; Henschel, V.; Germeyer, A.; vonWolff, M.\& Hamann, A. (2005). Early effects of metformin in women with polycystic ovary syndrome: a prospective randomized, double-blind, placebo-controlled trial. J. Clin. Endocrinol. Metab. 91(3):946-952.

14. Žaneta, K.; Gražina, D.\& Zita, K.( 2004). Serum leptin levels in pregnant women and umbilical cord: relationship to mother and neonate anthropometry. ACTA. Medica. Lituania. 11(3):26-30.

15. Bushra, H. (2002). Biochemical and clinical study of polycysticovary syndrome and the effect of clomiphene citrate on hormones, leptin and trace elements. MSc. Thesis. College of Science. Al-Nahrain University. pp. 39.

16. Vuppugalla, R.; Agarwal, V.\& Khan, M.A. (2003). A simple HPLC method for the simultaneous analysis of insulin and ovomucoid. Pharmazie. 58(11):793-795.

17. Iverson, C.L.; Christiansen, S.; Flanagin, A.F.\& Fontanarosa, P.B. (2007) . Glass RM, Gregoline B, AMA Manual of Style: A Guide for Authors and Editors.10th ed. New York, NY: Oxford University. Pp.798.

18. Reitman, M.L.; Bi, S.; Marcus-Samuels, B.\& Gavrilova, O.(2001). Leptin and its role in pregnancy and fetal development-an overview. Biochem. Soc. Trans. 29(2):68-72.

19. Kim, K.H.; Kim, Y.J.; Lee, S.; Oh, S.W.; Lee, K.\& Park, Y. (2008). Evaluation of plasma leptin levels and BMI as predictor of postpartum weight retention. Indian. J. Med. Res. 128(5):595-600.

20. Alexe, D.M.; Syridou, G.\& Petridou, E.T.(2006). Determinants of early life leptin levels and later life degenerative outcomes. Clin. Med. Res. 4(4):326-335.

21. Masayo, Y.; Toshiya, M.\& Takeshi, I.(2003). Serum Leptin Levels in Women throughout Life; Relationship to Body Mass Index and Serum Estradiol Levels. Japaneas journal of reproductive endocrinology. 8: 55-60.

22. Sagawa, N.; Yura, S.; Itoh, H.; Mise, H.; Kakui, K.\& Korita,D.(2002). Role of leptin in pregnancy-A Review. Placenta. 17(3):110-138.

23. Loss,R.P.(2010).American Society for Reproductive Medicine. http://www.asrm. org/Literature/mainlit.html.

24. Practice Committee of the American Society for Reproductive Medicine.(2008). Definitions of infertility and recurrent pregnancy loss. Fertil 


\section{University of Thi-Qar Journal Vol.10 No.1 Mar 2015}

Web Site: https://jutq.utq.edu.iq/index.php/main Email: journal@jutq.utq.edu.iq

Steril.89(6):1603.

25. Grattan,D.R.; Ladyman, S. R.\& Augustine, R. A. (2007).Hormonal induction of leptin resistance during pregnancy. Physiol. Behav.91(4):366-374.

26. De Mouzon Sylvie, H.; Jacques, L.\& Patrick, C.(2006). The known and unknown of leptin in pregnancy. 194(6), pp. 1537-1545.

27. Yamada, M.; Matsuzaki, T.; Iwasa, T.; Shimizu, F. Tanaka, N.\& Ogata, R. (2003).Serum Leptin levels in women throughout life; Relationship to body mass index and serum estradiol levels. Japan Society of Reproductive Endocrinology.8:55-60.

28. Dudek, R. W.(2007). High- Yield Embryology. 2end edition. Ph.D. thesis. Greenville, North Caroline. Pp: 20-22.

29. Sadler, L. M. (2010). Clinically Oriented Embryology and Physiology. California University. Pp:21-27.

30. Sadler, L. M. (2010). Teratological Clinically and Clinical Correlation. California University. Pp:14-18 .

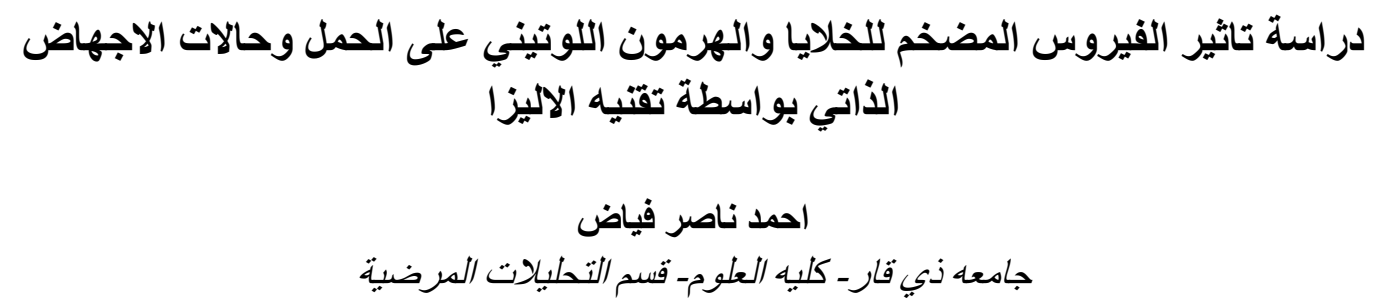

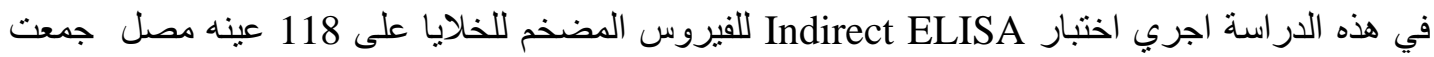

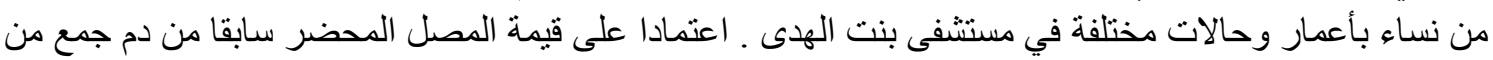

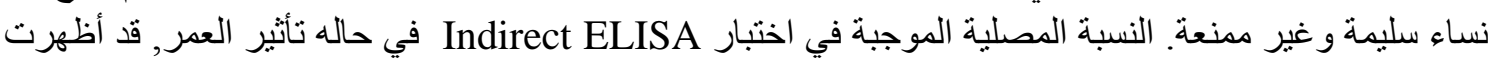

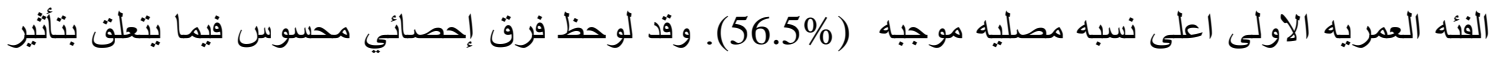

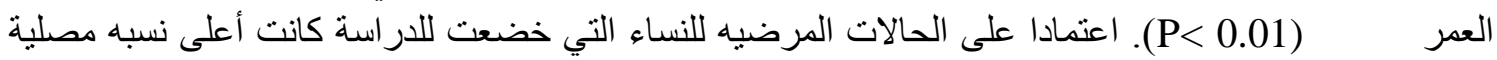

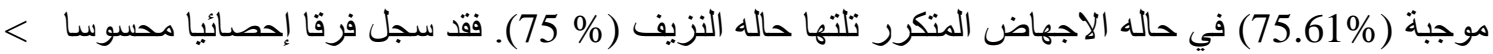

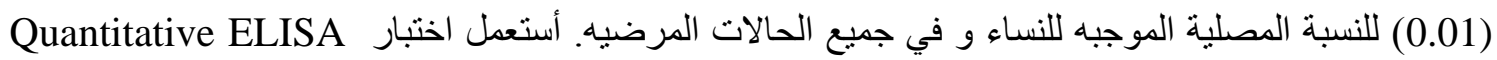

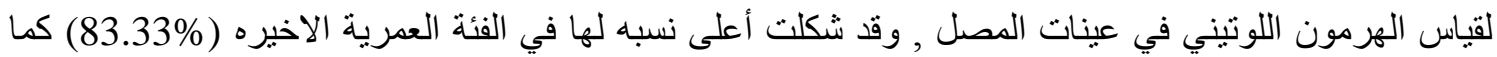

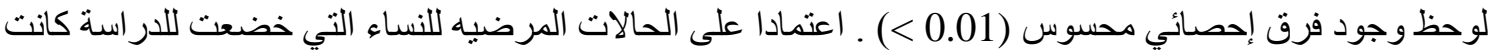

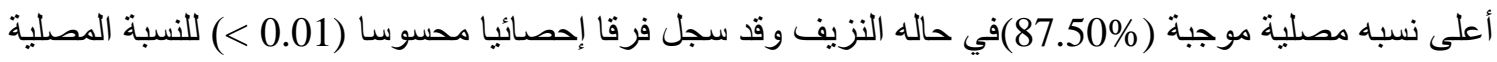
الموجبه للنساء و في جميع الحالات المرضيه. 